\title{
Assessing oral proficiency in computer-assisted foreign language learning: A study in the context of teletandem interactions
}

Avaliando proficiência oral na aprendizagem assistida por computadores: Um estudo no contexto de interações em teletandem

\author{
Douglas Altamiro Consolo \\ (UNESP - Universidade Estadual Paulista, Brazil) \\ Viviane Bagio FurToso \\ (UEL - Universidade Estadual de Londrina, Brazil)
}

\begin{abstract}
An innovative aspect in the area of language assessment has been to evaluate oral language proficiency in distant interactions by means of computers. In this paper, we present the results of a qualitative research study that aimed at analyzing features of language spoken in a computeraided learning and teaching context, which is constituted by teletandem interactions. The data were collected in the scope of the Teletandem Brazil project by means of interviews, audio and video recordings of online interactions, questionnaires and field notes. The results offer contributions for the areas of assessment, teacher education and teaching Portuguese for foreigners.
\end{abstract}

Key-words: Assessment; Foreign Languages; Synchronous Communication; Teletandem. 


\section{RESUMO}

Um aspecto inovador na área de avaliação em aprendizagem de línguas tem sido a avaliação de proficiência oral em interações com auxílio do computador. Neste artigo, apresentamos os resultados de uma pesquisa que objetivou analisar características de língua falada em um contexto online de ensino e de aprendizagem de línguas estrangeiras, constituido por interações em teletandem. Os dados foram coletados no projeto Teletandem Brasil, por meio de entrevistas, gravações em áudio e em vídeo de interações, questionários e notas de campo. Os resultados contribuem para as áreas de avaliação, de formação de professores e de ensino de Português para estrangeiros.

Palavras-chave: Avaliação; Línguas Estrangeiras; Comunicação Síncrona; Teletandem.

\section{Introduction}

To what extent can we talk about recent and significant changes in language assessment? Why have we studied and discussed assessment for such a long time and changes observed in school contexts have been so few? (cf.: Hoffmann 2005:67). These questions have motivated us to investigate more systematically the role of assessment in both language teaching and teacher education processes. And in conjunction with the aforementioned questions, a new scenario has appeared for those who dedicate to education: the online environment, in which computer-assisted language learning (CALL) stands. And this scenario, inasmuch as it hosts proposals and practices for language learning, has also motivated our reflections about language assessment in online contexts.

In this sense, speaking of evaluation in the context of distance education and in online environments consists of a challenge to those who believe in the potential of technology and see it as an ally in the teaching and learning processes.

With the increased opportunities for online interaction in various locations all over the world, the distance between users of a foreign language (FL) and the actual context of use of this target language 
ceases to be a limitation for interaction between people. This has resulted in linguistic-cultural exchanges, promoting greater closeness between peoples and awakening interest for foreign languages that were unknown until recently. As an example, we can highlight the status of the Portuguese language, which has gained recognized visibility abroad and optimization in initiatives for the learning of Portuguese in online environments. We could list several of these initiatives, however, due to the scope of this article, let us focus on investment of teachers and researchers in the field of language teaching for viable projects with a focus on FL learning. Highlights from representing initiatives of this nature include the Galanet Project (Melo 2004), in Europe, and "Teletandem Brazil: foreign languages for all, henceforth the TTB ${ }^{1}$ project (Telles 2009). Although the Galanet project and the TTB project have departed from different principles and goals ${ }^{2}$, both promote learning Portuguese language through online resources. The TTB project is the investigation context of this study.

Considering teaching, learning, teacher education and online assessment, the investigation ${ }^{3}$ reported here was guided by three issues mentioned in the current literature: 1. lack of recognition of the important role that assessment plays in the teaching-learning process; 2. the demand for adequate preparation of language teachers to deal with new information and communication technologies and 3. few studies on performance evaluation and on mediated interactions by means of online resources.

Based on the justifications mentioned so far, the aims of this study were to investigate the characteristics of oral proficiency assessment in the context of language teaching-learning at distance, in the teletandem context; and aspects of PSOL (Portuguese to Speakers of Other Languages) with views to contribute with language teacher education.

1. Detailed information can be found in www.teletandembrasil.org

2. Galanet project (European programme Socrates, www.galanet.eu) is a cross-comprehension modality for the teaching of Romance languages, giving a priority to the comprehension competence, based on the proximity of the different languages of the Romance family (Degache 2003). In the TTB project, pairs of either native or competent speakers learn each other's language by means of bilingual conversation (Telles and Vassallo 2006).

3. The complete thesis is available at http://vbfurtoso.wordpress.com/Thesis-doutorado/ (Furtoso 2011). 
We propose specific objectives based on three research questions that guided our study: 1. How is Portuguese spoken in an online learning context characterized?; 2. How can we conduct oral performance assessment in the context of teletandem?; and 3. Which should the parameters be for the assessment procedures in the TTB project?

Information was collected within the TTB project by means of audio and/or video recordings of teletandem sessions ${ }^{4}$, questionnaires applied to teletandem partners; teletandem tracking sheets and field notes made by researchers.

In order to present the results of the investigation mentioned above, this article is divided in three sections. In the first section, we present the theoretical framework that supported our study. Secondly, we approach the methodology of the research. Finally, we discuss the results of the study and present our final comments.

\section{Theoretical Framework}

An investigation about language assessment in a mode of telecollaboration as Teletandem, a virtual, collaborative and autonomous context for learning foreign languages that adopts the three principles of tandem learning: autonomy, reciprocity, and separate use of both languages (Telles, in this issue), let us to explore its most varied asepcts.

After raising aspects considered relevant to the area of foreign language teacher education and the relationship with assessment practices mentioned in the introduction of this paper, we discuss specific issues in the area of PSOL, on the understanding that they need to be brought to this research in the light of the contributions already offered by other studies. Among the issues addressed in our investigation are a historical overview (Furtoso 2001; Furtoso 2005); aspects of teacher

4. "These sessions are voluntarily established by two speakers of different languages. They may or may not be native, they are not professional teachers, and both are interested in studying the language in which the other is more proficient". (Vassallo and Telles 2006:2). "They may be either chronologically subsequent to each other or done in two different days, but each part must be devoted to only one language (first Tandem principle: languages must not be mixed)". (Vassallo and Telles 2006:5). 
education (Furtoso 2001, 2009; Cunha and Santos 1999, 2002; Grannier 2003); lack of studies in the area of PSOL assessment (Scaramucci 1997; Furtoso 2011); the Celpe-Bras Examination (Brasil 2006; Schlatter 1999; Scaramucci 1999; Cunha and Santos 1999), descriptors of oral proficiency assessment in the Celpe-Bras Examination (Schoffen 2003) and characteristics of the Portuguese language spoken in Brazil (Castilho 1989; 1990; 1998; Marcuschi 1986, among others).

As an important agency of linguistic policy, the Celpe-Bras examination certifies its candidates on their language proficiency in Portuguese as a foreign language. The examination is elaborated and administered by the Brazilian Ministry of Education, and it is applied in Brazil and in a number of other countries worldwide. It is the only certificate in Portuguese as a foreign language recognized by the Brazilian government and it is compulsory for foreigners who wish to pursue undergraduate or postgraduate studies in Brazilian universities, as well as for professionals who apply to validate their foreign diplomas in order to work in Brazil. ${ }^{5}$

In a second part of the theoretical framework, language assessment is contemplated in its most diverse aspects: evaluation as an integrative element between teaching and learning (Scaramucci 1993, 2006; Hadji 2001); assessment of foreign language proficiency (Consolo 2004, 2007; Brasil 2006; Shohamy and Inbar 2006a; 2006b; Schlatter et al. 2005; 2009; Schlatter 1999; Schoffen 2003; 2009; Dell'Isola et al. 2003; McNamara 1996); peer assessment (Consolo 2010; Saito 2008; Dochy, Segers and Sluijsmans 1999; Stefani, 1994). To discuss the issue of online assessment, we resorted to the literature about distance education with some topics already identified, namely: models of distance education (Gomes 2008); assessment in online education (Gomes 2009; 2010; Barreiro-Pinto and Silva, 2008; Silva and Santos, 2006; Rosa and Maltempi 2006; Garrison and Anderson 2003); the use of ICT (Information and Communication Technologies) in education and the concept of e-learning (Gomes 2005); the concept of telecooperation (O'Dowd 2007); the use of technology in language learning (Paiva 1999; Araújo 2007); feedback in interactions in virtual environment (Paiva 2003; Furtoso 2009); language learning in tandem (Cziko and

5. Our translation into English from the webpage http://celpebras.inep.gov.br/inscricao/ 
Park 2003; Brammerts 2006; Vassallo and Telles 2006;); and teletandem (Telles and Vassalo 2006; Telles 2009), among others.

From researches carried out in the scope of TTB, we highlight the ones focused on: linguistic-cultural aspects (Fernandes 2008; Silva 2008; Santos 2008; Martins Moiteiro 2009; Brocco 2009); teacher education (Kaneoya 2008; Bedran 2008; Mendes 2009; Candido 2010); self-evaluation and beliefs of evaluation practices (Mesquita 2008; Cavalari 2009); management and pedagogical strategies in the partners' mediation (Salomão 2008; Da Rocha 2009); development of autonomy (Luz, 2009): power relations (Vassallo 2010) and agreement and negotiation in the teletandem context (Garcia, 2010). Although these studies have not been explicitly related to the area of Portuguese to Speakers of Other Languages, they discuss relevant issues about the context where the Portuguese is learned as a foreign language. In this sense, they have put questions to future researches to be developed by the ones interested in the area of PSOL.

From this framework, which supported the study, we report on the methodological procedures.

\section{Research methodology}

In Applied Linguistics, the area this study stands in, interpretative procedures have been a recommended methodological approach to achieve more valid research findings and new insights in teaching and learning contexts.

Research results in Applied Linguistics have shown how complex it is to analyze the processes that involve human beings and their worlds. Therefore, what has been done is to study the situations under their specific conditions without intending to generalize the results obtained.

Concerning the aims of this study, the qualitative research paradigm (Chaudron 1988; Burns 1999; Bogdan and Biklen 1992; Erickson 1986, 1991) and an ethnographic approach (André 2000) were selected to collect, analyze and categorize the data. The methods of inquiry were chosen due to the importance of taking into account the participants' 
views about the study object, including the researchers' views as well.

The information was collected in the scope of the Teletandem Brazil project (TTB), at the UNESP-Assis lab, by means of interviews, audio and video recordings of teletandem conversation, questionnaires, teletandem tracking sheets and field notes. These instruments provided the researchers with important particular aspects of the teaching, learning and assessing in the teletandem context.

The Brazilian participants were Letras students from UNESP Assis and the foreigner participants were students of Portuguese at State University of Londrina (UEL), the institution of one of the researchers. In the data samples, presented in section 3, the participants are referred to as BP (Brazilian partner) and FP (foreigner partner). The study counted on four partnerships.

The data were categorized according to the contents obtained by means of each type of research instrument and analyzed with the support of the theoretical framework presented in section 1 of this article. The spoken language analysis, more specifically, was based on the textualinteractive approach of Portuguese spoken in Brazil (Castilho 1998) what, in fact, meant an innovative theoretical framework within the TTB project.

\section{Results}

In the chapter of the thesis that generated the data we discuss in this section of the article, the analysis was focused on both the development of the three phases initially proposed for the teletandem session, the conversation, the linguistic feedback and the self-assessment, and the learning and evaluation processes in the TTB project. The latter departed from the teletandem track sheet and from the implications of its use for the self and peer assessment, taking into account the features of the spoken Portuguese in the online context.

The results are discussed here according to the research questions proposed initially. 
The analysis of spoken Portuguese in teletandem sessions, which was incorporated into the categories derived from the analysis of the recorded data, was conducted on the basis of Linguistic theories about the Portuguese spoken in Brazil, as mentioned before.

The results showed that the construction of spoken Portuguese in teletandem sessions was featured by the presence of frequent stops during the conversation. According to the theories we based on, these stops are called parenthetical inserts (Castilho 1998). They can be noticed when the participants of a teletandem session stop what they are talking about to explain something, either linguistic aspects or other content, to their partners, that is, the partners co-construct meaning in order to go on and maintain the conversation.

For example, parenthetical inserts for clarification of form and content, with the presence of phenomena like paraphrasing, corrections and repetitions, were present in the speech of the participants of our study.

The example below illustrates a parenthetical insert of form that occurred at the beginning of the teletandem session between a Brazilian partner (BP) and an English speaker, the learner of Portuguese (FP). The foreigner partner used English words, "high school", to express that he did not know how to say that in Portuguese, and such fact interfered with the development of a topic being discussed, about what BP had done over the weekend. Let us see how BP explained vocabulary to his partner:

BP: que que aconteceu de tão bom?

[what what happened that was so good?]

FP: ahn:: (+) não sei havia muito gente ahn:: do meu ah:: high school

[ahn:: (+) I don't know whether there were a lot of people ahn:: from my ah:: high school]

BP: ah::

FP: como é hi high school? [how do you say high school?]

BP: do do ensino Médio

[from from high school]

FP: ok $(+)$

BP: ((digitando)) / [((typing) $)]$ 
FP: si

[yes, in Spanish]]

BP: ((digitando)) / [(typing) $)]$

FP: ok

FP: que eh:: significa ensino?

[what does eh ensino mean?]

BP: ensino?

[teaching?]

FP: ahã si

[ahã Yes, in Spanish]

BP: ahn:: $(+)$ eh:: em inglês a gente usa teaching [ahn:: (+) eh:: in English we use teaching]

(Partnership 1)

Once the foreigner partner had his doubts about the lexicon clarified, the conversation made sense and the participants returned to the main topic of their interaction.

Other examples of parenthetical inserts for clarification of doubts about vocabulary can be seen in the next two examples:

FP então $(+)$ ahn:: como se diz agree"

[so $(+)$ ahn:: how can I say agree"]

((the foreigner partner said the sentence in Portuguese but used the word "agree" in English))

BP con-cor-dar ((digitando))

[the Brazilian partner said the word in Portuguese and typed it]

FP ok então eu concordo

[OK so I agree] ((the foreigner partner used the word correctly in Portuguese))

(Partnership 4)

FP ahn mas não sei se (+) ahn:: como como é (I would want) queria"

queria"

[ahn but I don't know if (+) ahn::how can I say "I would want"] ((the foreigner partner said the sentence in Portuguese but used "I would "like" in English followed by the appropriate word in Portuguese - "queria".))

BP $\operatorname{sim}(+)$ é correto correto queria"

[Yes (+) it's right right "queria"] ((repeating the appropriate word in Portuguese)) 
BP sim tá correto

[Yes that's right]

FP ok não sei se eu queria $(+)$ dois pais assim ou $(+)$ se

[ok I don't know whether I would want $(+)$ two fathers like that or (+) if]

BP ou duas mães

[or two mothers]

(Partnership 4)

The examples above show these moments when the partners interrupt the flow of conversation about a topic other than language, in order to clarify form. These moments are important and necessary for the maintenance of the conversation, as they allowed for better learning and understanding of the language being used. The lack of explicit definitions or contextualization of lexicon, for example, could make the interactions less successful, especially if we take into account the importance of the lexicon in the construction of a text.

Moreover, the teletandem context allows the partners to share written texts and images to clarify vocabulary doubts through the resources available on the internet, as Telles (in this issue) contextualized. One example of this was found in the data that illustrate an occasion when a French partner could not understand the word "alça" (ring) from a written text they were reading and discussing during a teletandem session. The Brazilian partner tried to explain it orally, but when she realized her explanation had not been enough to help the foreigner partner, she showed her partner an image using internet resources, as we can see below.

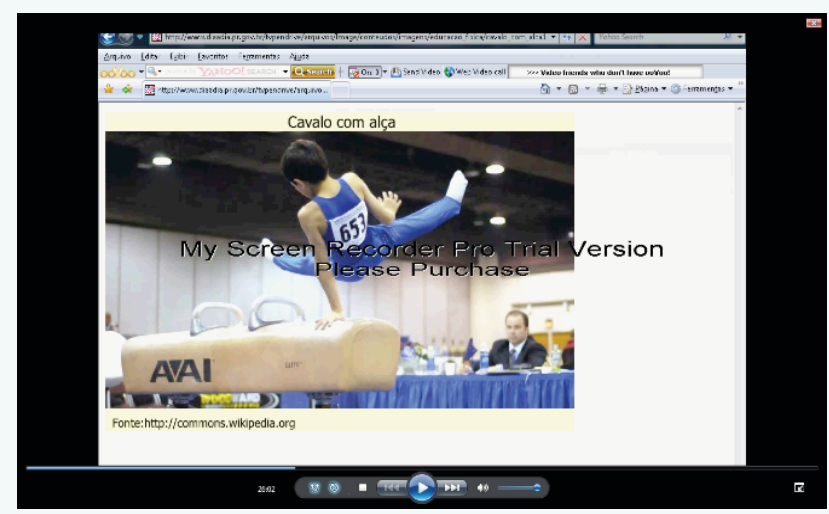


The end of this part of the conversation, when BP and FP spoke about the image to illustrate the word "alça", is shown below:

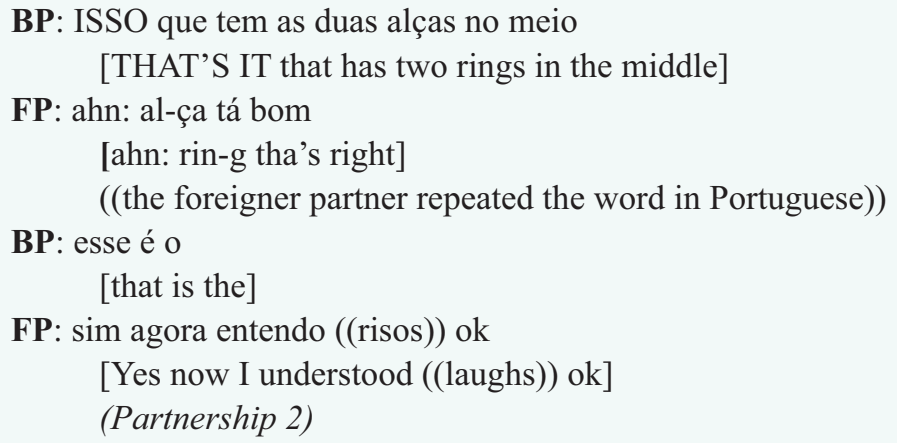

Besides the linguistic feedback, as shown in the examples above, it was observed the importance of filling the cultural gaps during the conversation, what the most proficient partner in the target language usually does. Let us consider the following excerpt:

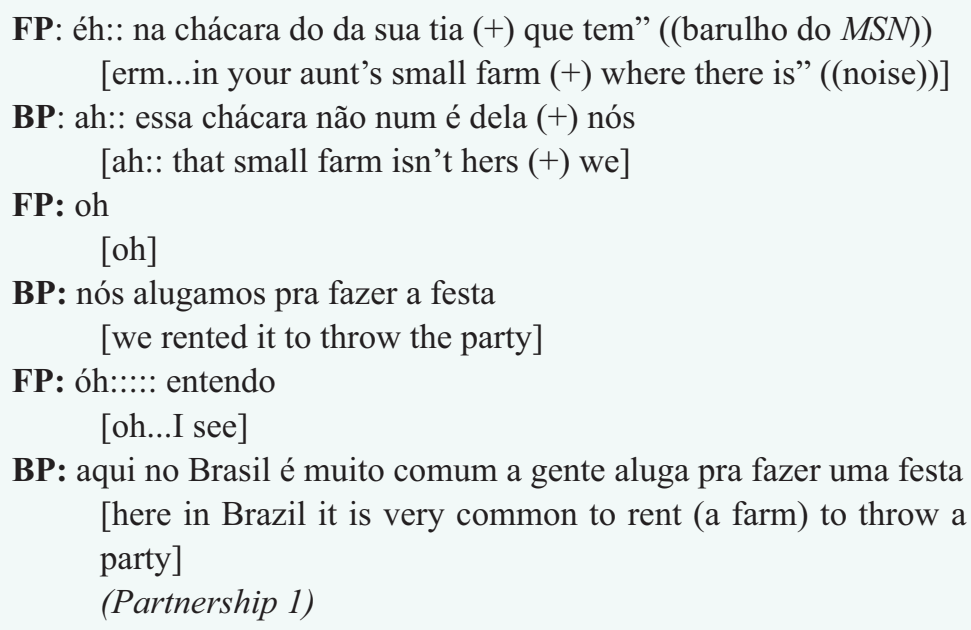

BP: aqui no Brasil é muito comum a gente aluga pra fazer uma festa [here in Brazil it is very common to rent (a farm) to throw a party] (Partnership 1)

This excerpt and other examples found in the data show how language and culture are associated in the language learning and teaching process. Sometimes the cultural feedback is motivated by the occurrence of linguistic features, sometimes cultural information motivates the development of the conversation so as to discuss language used according to cultural elements. Thus, the parenthetical inserts 
extend the scope of the clarification of form and content towards further knowledge of the language and its culture, and even the use of communication tools available on the Internet. Therefore the quality of feedback on cultural aspects provided to one's partner is fundamental to the process of languages in the online context.

We agree with Salomão (in this issue) that it is necessary to review the language teaching knowledge base regarding intercultural communication and the teaching and learning of culture, "which should spur discussions grounded in real world interaction and nurtured by technological tools, in order to generate the opportunity for dialogically undergoing experiences, such as the ones provided by telepresence in teletandem".

Taking into consideration the role of the feedback in the learning process, inserts like the ones presented before, clarifying both form and content, allow a more detailed and individualized follow up. Many times, this kind of follow up does not happen in face-to-face learning.

Considering that the feedback process is part of the evaluation practice, we now move our attention to the importance of the different moments of feedback for the development of the teletandem partners' proficiency in the foreign language learned.

Based on initial conversations with the participants for data collecting and during a workshop on criteria for evaluating oral proficiency offered to the Brazilian participants at UNESP-Assis, we realized that evaluation was somehow being left aside during teletandem sessions.

If we consider that the last two parts of a teletandem session ${ }^{6}$ ( $50 \%$ of the interaction time) were meant to be dedicated to evaluation, including linguistic corrections, identifying the potential

6. As proposed in the initial project, a teletandem session was supposed to last on average two hours: one hour for each of the languages. Each hour should be composed of three basic phases: conversation about one or several themes (approximately 30 minutes) - partners talk about what they wanted or which was of common interest; linguistic input (about 20 minutes) - the most competent partner made comments on the use of lexis, grammar and pronunciation of his or her interlocutor; evaluation of the session (approximately 10 minutes) (Telles and Vassallo, 2006). 
of such process in teletandem could offer contributions for optimizing cooperative learning, once the assessment is part of the learning process and could have an important washback effect in the management of interactions.

The data from information obtained by means of questionnaires and by synchronous interactions conducted with teletandem partners showed that there was a tendency to perform linguistic feedback during the conversation, which was justified by the students as a matter of time saving procedures. Recognizing that the moments dedicated to clarifications are necessary for the maintenance of conversation and the continuity of interaction, we noted that the context of teletandem had been reorganized, since practice had shown that the linguistic feedback during the conversation was more productive than if offered just at the end of the conversation, as suggested in the instructions for the participants.

We can relate the feedback mechanism in teletandem to formative assessment. This process allows teletandem partners to receive immediate feedback on their linguistic production, especially when feedback is necessary for the conversation to flow, making the process an example of contextualized and meaningful language learning. For features of feedback to writing see Aranha and Cavalari (in this issue).

As regards self-assessment, the results showed that there was an overlap between self-assessment and the so-called linguistic feedback phases, i.e. we observed that partners did not distinguish feedback from self-assessment and indicated linguistic corrections as the focus of both phases.

We believe that self-assessment has the function of diagnosing advances for each of the partners in the learning process, in addition to reflecting upon specific difficulties concerning interaction in teletandem, and trying to identify their causes. In this sense, self-assessment can resume what was discussed in the linguistic feedback phase, but needs to go beyond the purely linguistic issues, including issues concerning the cooperation from each participant, their engagement, the development of sessions, among other issues for which assessment can have a positive washback effect in the learning process. 
Students seemed to be confused about what exactly they should do in each phase of a teletandem session, and they lacked preparation in order to carry out assessment. With a more solid formation on evaluation, the students could practice self-assessment, i.e. students need to learn to self-assess by referring to explicit instruments and criteria to do so. For the Brazilian participants in this study, future foreign language teachers, the task of assessing the other partner seemed to be even more difficult. This ratifies the need for preparation for evaluation.

In relation to the assessment criteria, proposed in the document that accompanies instructions for teletandem sessions and analyzed in comparison with scales for oral proficiency assessment ${ }^{7}$ used in face-to-face evaluation contexts, the results of our study show that oral comprehension tends to be similar to face-to-face contexts for most participants, but production is more difficult. In addition, the interaction is more tiring in the online context, it demands more effort and therefore, for the interaction to be pleasant and to result in reciprocal partnership (we need both partners feel that the other participant is really striving to contribute to his or her partner's language learning), revealing one of the pillars of teletandem, that is reciprocity.

Another criterion that deserves attention is fluency. When focusing on the online context, we observed frequent occurrences of discourse markers, which are less observed in data from studies on the Portuguese spoken in Brazil in face-to-face contexts. The presence of markers addressed to the listener, for example, can be justified by the need of the interlocutor to mark presence and demand attention during synchronous computer-mediated interactions, which also justify the presence of lines shorter than those produced by interlocutors when sharing the same physical context and temporal dimension. Besides,

7. Some selected rating scales applied in four different contexts, with focus on the criteria and descriptors referring to assessment of oral production and comprehension, were analysed to support this study: the Celpe-Bras Examination (Certificate of Proficiency in Portuguese for Foreigners), the EPO (Oral Proficiency Interview) of the American Council of foreign language teaching, CEFRL (Common European Framework of Reference for Languages) and the TEPOLI (Test of Oral Proficiency in English). All of these rating scales and the bibliographical references for the tests and frameworks can be found in Furtoso (2011), available at h ttps://vbfurtoso.files.wordpress.com/2011/09/tese_vivianeaparecida-bagio-furtoso.pdf 
resource that favors the use of paralinguistic features (gestures, facial expressions) instead of purely linguistic items only, as it occurs when the interlocutors share the same physical space during an interaction, which reiterates the need for constant use of suprasegmental linguistic elements (voice raising, intonation, stretching, pauses) and segmental (non-verbalized emotions/ahn, uhn, lexical elements, propositions). In this sense, when assessing oral proficiency in online contexts it is important to observe the proper use of markers so that the conversation has a more natural flow. Therefore, we believe that the descriptor(s) targeted for fluency should contemplate this specificity of the language spoken in online context.

Other criteria, namely lexicon and pronunciation, were raised by the participants with little or almost no difference when compared to the face-to-face context, although in a holistic assessment, lexicon and pronunciation were considered to determine the quality of fluency.

For Gomes (2009:1688), when using resources like Skype, "we are facing a trial scenario very similar to an occasion of an oral evidence or an oral presentation and discussion of a work performed face-to-face", which can justify the little difference between oral communication in the contexts of teletandem and face-to-face encounters, as revealed by the data analysis in this study.

The results obtained so far make us reflect on the proximity between the face-to-face interactions and synchronous interactions enabled by means of contexts such as teletandem. In terms of evaluation, the teletandem environment also offers to the speakers of foreign languages a real context of language use, different from situations created by computer programs that allow language users to interact with a machine, a situation in which their proficiency is evaluated without considering the unpredictability of the intervention of an interlocutor in language use.

Finally, we highlight the abundance and variety of features available in the teletandem context. The speech can be complemented by writing, through resources of the Internet and the use of online dictionaries, mainly in case of doubts in relation to the lexicon, spelling and pronunciation. Moreover, the topics can be expanded by means of the technical resources that partners can make use and the chance 
to provide to one another, within the same temporal axis, access to written texts, images, songs and supplementary information regarding the topics under discussion.

To conclude this section, it is important to say that during the investigation we, researchers and teletandem participants, proposed some changes, from the results presented so far, for the teletandem tracking sheet that was filled after each session by the teletandem partners.

From the results of our study, the act of filling out the tracking sheet is a way to develop learners' autonomy when learning a foreign language. The tracking sheet can be considered helpful mainly because it is supported by the two paradigms that focus on assessment. The first one, self-evaluation, for being the mode of assessment that most values the concept of language for authentic communication, and language within the co-construction of theoretical knowledge, pillars underpinning tandem learning. The second paradigm, which focuses on evaluating the performance one's partner, help each participant to reflect on his or her own learning objectives and can prepare, as so informed, teachers-to-be to work as foreign language teachers, in the case of Brazilian partners in the TTB project.

\section{Final comments}

By accepting the challenge of addressing innovative aspects in the area of language proficiency assessment (Consolo 2006), the study reported in this article aimed at identifying characteristics of the language used in the teletandem interactions, with focus on spoken Portuguese, and suggesting ways of optimizing the processes of language assessment and the education of language teachers.

As we consider the teletandem an online foreign language learning context as a meaningful way for optimizing the learning of both foreign languages in Brazil and Portuguese abroad, as well as a way to contribute with teachers education, we presented the TTB project as the main investigation context of this study. 
Summarizing the results, we can state that the teletandem conversation is a linguistic and cultural interchange between Brazilian and foreigner partners powered by the feedback provided during the sessions. The partners' intervention to help each order in relation to linguistic and cultural aspects during the conversation is essential to contextualize and keep the progress of interaction, as well as to provide the support required in order to acknowledge and give attention to the interlocutor's speech.

Taking into account the features of the spoken language in online conversation, the characteristics of natural speech flow, described in language proficiency assessment scales, should be more carefully investigated, mainly the linguistic aspects related to criteria such as oral comprehension, fluency and interactional competence.

As part of the TTB activities, the teletandem tracking sheet showed to be a powerful assessment instrument to promote collaborative learning. The strength of this kind of learning and evaluation trigger was observed by the opportunities in providing the teletandem partners with a more formative feedback, supporting both the self-evaluation and the peer assessment processes. However, the benefits it can bring to a FL online context cannot be guaranteed unless students are capable of implementing assessment practices.

In the teaching perspective, evaluating the partner's performance was seen as a challenging activity in the teletandem context. From this, we conclude that: 1 . Brazilian participants need to be prepared to teach Portuguese to Speakers of Other Languages (it is going to be reinforced through other studies in this issue, i.e. by Ramos, in next chapter, Carvalho, Messias and Dias and others); 2. teacher education practices in Brazil have not focused on discussions about assessment as they should (Aranha and Cavalari's study, in this issue, reinforces it when suggests a gap on the teachers-to-be education concerning written feedback provision). In our opinion, evaluating can also help us to self-evaluate, as well as to offer a more appropriate feedback for our students.

This study raised additional thoughts about the role that the practice of teletandem - that is, to engage in synchronous interactions by means of computers, can assume as a parallel practice to what is done in the 
foreign language classroom. Both in Brazil and abroad, teletandem partnerships have been formed by students who are learning a foreign language in Brazil and the Portuguese language overseas. So why not take into account the practice of teletandem as part of the programs of school subjects? And yet, why not consider student production during teletandem sessions for assessing his or her language learning process? It seems that this has also happened as some partnerships were consolidated between Brazilian and abroad universities, as Telles (in this issue) mentioned. These practices deserve consideration, whose implications may contribute with knowledge about assessment in the online context.

Received in March, 2015

Accepted in August, 2015

E-mails:

dconsolo@terra.com.br viviane@uel.br

\section{References}

ANDRÉ, Maria Eliza. 2000. Etnografia da prática escolar. 4. ed. Campinas: Papirus.

ARAúJo, Júlio César. Ed. 2007. Internet \& Ensino: novos gêneros, outros desafios. Rio de Janeiro, Brazil: Lucerna.

Barreiro-Pinto, Isabel Andréa.; Silva, Marco. 2008. Avaliação da aprendizagem na educação online: relato de pesquisa. Educação, Formação \& Tecnologias; vol.1 (2); 32-39, nov. 2008. Available at: $<$ http://eft.educom.pt $>$.

Bedran, Patrícia Fabiana. 2008. A (re)construção das crenças do par interagente e dos professores-mediadores no teletandem. Dissertation (Master's in Linguistic Studies) - São Paulo State University, São José do Rio Preto, São Paulo, Brazil.

Bogdan, Robert \& BiKlen, Sara Knopp. 1992. Qualitative research for education: An introduction to theory and methods. Boston: Allyn and Bacon.

BRAMMERTS, Helmut. 2006. Language learning in tandem: definition, tandem principles, tandem organizers, bibliography. 1995-2000. Available at: http://www.slf.ruhr-uni-bochum.de/learning/idxeng11. $\mathrm{html}$ and accessed in March 2006. 
Brasil. 2006. Manual do aplicador do Exame Celpe-Bras / Secretaria de Educação Superior. Brasília: MEC.

Brocco, Aline de Souza. 2009. A gramática em contexto teletandem e em livros didáticos de português como língua estrangeira. Dissertation (Master's in Linguistic Studies) - São Paulo State University, São José do Rio Preto, São Paulo.

Burns, Anne. 1999. Collaborative action research for English language teachers. Cambridge: Cambridge University Press.

CAndido, Juliana. 2010. Teletandem: sessões de orientação e suas perspectivas para o curso de Letras. Dissertation (Master's in Linguistic Studies) - São Paulo State University, São José do Rio Preto, São Paulo, Brazil.

Castilho, Ataliba Teixeira de. 1989. Português culto falado no Brasil. Campinas, Brazil: Editora da UNICAMP.

. 1990. O português culto falado no Brasil: história do projeto NURC/BR. In: Dino Preti \& Hudinilson Urbano. Eds. A linguagem falada culta na cidade de São Paulo. São Paulo: T. A. Queiroz Editor, 141-155.

. 1998. A língua falada no ensino de português. São Paulo, Brazil: Editora Contexto.

Cavalari, Suzi Marques Spatti. 2009. A auto-avaliação em um contexto de ensino-aprendizagem de linguas em tandem via chat. Thesis (Doctorate in Linguistic Studies) - São Paulo State University, São José do Rio Preto, São Paulo, Brazil.

Chaudron, Craig. 1988. Second language classrooms: research on teaching and learning. Cambridge: Cambridge University Press.

Consolo, Douglas Altamiro. 2010. Princípios e procedimentos para avaliação em meios eletrônicos: implicações para a aprendizagem de línguas em teletandem. In: A. M. Benedetti, D. A. Consolo \& M. H. Vieira-Abrahão. Eds. Pesquisas em ensino e aprendizagem no Teletandem Brasil: línguas estrangeiras para todos. Campinas, SP: Pontes Editores: 283-296.

. 2007. Avaliação de proficiência oral: uma reflexão sobre instrumentos e parâmetros na formação do (futuro) professor de língua estrangeira. In: Maria Luisa Ortiz Alvarez \& Kleber Aparecido da Silva. Eds. Lingüistica aplicada: múltiplos olhares. Campinas: Pontes: $109-118$.

.2006. A interação em língua estrangeira em situações de e-tandem: influências no processo de aprendizagem e características lingüísticas da produção oral. Research Project (mimeo). 
.2004. A construção de um instrumento de avaliação da proficiência oral do professor de língua estrangeira. Trabalhos em Lingüística Aplicada, v. 43, n. 2, 265-286.

Cunha, Maria Jandira \& SAntos, Percília. Eds. 1999. Ensino e pesquisa em português para estrangeiros. Brasília, Brazil: Editora da UnB.

Eds. 2002. Tópicos em português língua estrangeira. Brasília, Brazil: Editora da UnB.

CzIKo, Gary \& PARK, Sujung. 2003. Internet audio communication for second language learning: a comparative review of six programs. Language Learning \& Technology, v. 7, n. 1, 15-27.

DA RochA, Suzana. 2009. Ameliorer l'accompagnement dans les partenariats de teletandem francobresiliens. Master Arts, Lettres, Langues, Communication. Université Charles-de-Gaulle. Lille III, France.

Degache, Christian. 2003. Romance cross-comprehension and language teaching: a new trend towards linguistic integration in Europe. The Galanet project solution, Communication presented at The International Conference. Teaching and learning in higher education: new trends and innovation, Universidade de Aveiro (Portugal), 1317/04/2003. Available at: <www.galanet.eu/publication/fichiers/ dc2003a.pdf $>$.

Dell'Isola, Regina Lúcia Péret et al. 2003. A avaliação de proficiência em português língua estrangeira: o exame CELPE-Bras. Revista Brasileira de Lingüística Aplicada, v. 3, n 1, 153-164.

Dochy, Filip, Segers, Mien \& SLuissmans, Dominique. 1999. 'The use of self-, peer and co-assessment in higher education: a review'. Studies in Higher Education, v. 24, n. 3, 331-350. Available at: <http://dx.doi. org/10.1080/03075079912331379935>.

ERICKSON, Frederick. 1986. Qualitative methods in research on teaching. In Merlin C. Wittrock. Ed. Handbook of Research on Teaching, New York: Macmillan, 119-161.

1991. Advantages and disadvantages of qualitative research design on foreign language research. In: B. Freed. Ed. Foreign Language Acquisition Research, D.C.: Heath \& Company, 338-353.

Fernandes, Fábio Roberto. 2008. Investigando o processo de ensinoaprendizagem em LE in-tandem: aprendizagem de língua francesa em contexto digital. Dissertation (Master's in Linguistic Studies) - São Paulo State University, São José do Rio Preto, São Paulo, Brazil.

FurToso, Viviane Aparecida Bagio. 2011. Desempenho oral em português para falantes de outras línguas: da avaliação à aprendizagem de línguas estrangeiras em contexto online. Thesis (Doctorate in 
Linguistic Studies) - São Paulo State University, São José do Rio Preto, São Paulo, Brazil.

2009. Para além do "Gostei muito da conversa": avaliação no contexto de aprendizagem in-tandem. In: J. A. Telles. Ed. Teletandem: um contexto virtual, autônomo e colaborativo para a aprendizagem de línguas estrangeiras no século XXI, Campinas, Brazil: Pontes Editores, 297-314.

.2005. Português para falantes de outras línguas: institucionalização nas universidades brasileiras e publicações. In: K. M. P. Gimenez. Ed. Contribuições na área de línguas estrangeiras. Londrina, Brazil: Moriá: 120-130.

2001. Português para falantes de outras línguas: aspectos da formação do professor. Dissertation (Master's in Language) - State University of Londrina, Londrina, Brazil.

FurToso, Viviane Aparecida Bagio. Ed. 2009. Formação de professores de português para falantes de outras línguas: reflexões e contribuições. Londrina, Brazil: EDUEL.

Garcia, Daniela Nogueira de Moraes. (2010) Teletandem: acordos e negociações entre os pares. 2010. Thesis (Doctorate in Linguistic Studies) - São Paulo State University, São José do Rio Preto, São Paulo, Brazil.

GARRISON, Randy \& ANDERSON, Terry. 2003. E-learning in the $21^{\text {st }}$ century: a framework for research and practice. London: Routledge Falmer.

Gomes, Maria João. 2005. Desafios do E-learning: do conceito às práticas. In: Actas do VIII Congresso GalaicoPortuguês de PsicoPedagogia. Braga, Portugal: CIEd /IEP / UM [CD-ROM], 66-76. 2010. Problemáticas da avaliação em educação online. In: M. Silva, L. Pesce \& A. Zuin. Eds. Educação online: cenário, formação e questões didático-metodológicas. Rio de Janeiro: WAK: 309-336. . 2008. Na senda da inovação tecnológica na educação a distância. Revista portuguesa de pedagogia, v. 2, ano 42, 181-202.

2009. Problemáticas da avaliação em educação online. In: Actas da Conferência Internacional de TIC na educação: challenges; Braga, Portugal: Universidade do Minho, 1675-1693.

Grannier, Daniele Marcelle. 2003. As bases e a diversificação na formação de professores de português como segunda língua. In: Eberhard Gärtner / Maria José Peres Herhuth / Nair Nagamine Sommer (eds.) Contribuições para a Didáctica do Português Lingua Estrangeira Actas do IV Congresso da Associação Alemã de Lusitanistas. Frankfurt, Alemanha, 331-341. 
Hadj, Charles. 2001. Avaliação desmistificada. Porto Alegre, Brazil: ARTMED Editora.

Hoffmann, Jussara. 2005. O jogo contrário em avaliação. Porto Alegre, Brazil: Mediação.

KAneoya, Marta Lúcia Cabrera Kfouri. 2008. A formação inicial de professores de línguas paralem contexto mediado pelo computador (teletandem). Thesis (Doctorate in Linguistic Studies) - São Paulo State University, São José do Rio Preto, São Paulo, Brazil.

Luz, Emeli Borges Pereira. 2009. A autonomia no processo de ensino e aprendizagem de linguas em ambiente virtual (teletandem). Dissertation (Master's in Linguistic Studies) - São Paulo State University, São José do Rio Preto, São Paulo, Brazil.

MARCUSCHI, Luiz Antônio. 1989. Marcadores conversacionais do português brasileiro: formas, posições e funções. In: A. T. de Castilho. Ed. Português culto falado no Brasil. Campinas, Brazil: Editora da Unicamp, 281-321.

. 1986. Análise da Conversação. São Paulo, Brazil: Editora Ática.

Martins Moiteiro, Nicole. 2009. Action research on Teletandem: an analysis of virtual intercultural communication between students from Brazil and Germany. Diplomarbeit. Germersheim: JohannesGutenberg-Universität Mainz.

McNamara, Tim. 1996. Measuring second language performance. Edinburgh Gate: Addison Wesley Longman Limited.

Melo, Sílvia. 2004. A utilização das TIC no ensino-aprendizagem de línguas: o projecto Galanet no contexto europeu de promoção da intercompreensão em línguas românicas - o caso do PLE. In: Conferência Internacional da Brasa, Rio de Janeiro, Brazil.

Mendes, Ciro Medeiros. 2009. Crenças sobre a língua inglesa: o antiamericanismo e sua relação com o processo de ensinoaprendizagem de professores em formação. Dissertation (Master's in Linguistic Studies) - São Paulo State University, São José do Rio Preto, São Paulo, Brazil.

Mesquita, Alexandre Alves França de. 2008. Crenças e práticas de avaliação no processo interativo e na mediação de um par no tandem a distância: um estudo de caso. Dissertation (Master's in Linguistic Studies) - São Paulo State University, São José do Rio Preto, São Paulo, Brazil.

O'Dowd, Robert. 2007. Evaluating the outcomes of online intercultural exchange. ELT Journal, v. 61, n. 2, 144-152.

Paiva, Vera Lúcia Menezes de Oliveira. 1999. O papel da educação a distância na política de ensino de línguas. In: Mendes et al. Eds. 
Revisitações: edição comemorativa: 30 anos da Faculdade de Letras/ UFMG, p. 41-57. Belo Horizonte, Brazil: UFMG/FALE. Available at: http://www.veramenezes.com/ead.htm and accessed on 09 June 2007, 41-57.

2003. Feedback in the virtual environment. PsychNology Journal, v. 1, n. 3, 256-282.

Rosa, M.; MaLtemPI, M. V. 2006. Avaliação vista sob o aspecto da educação a distância. Ensaio: aval. pol. públ. Educ., Rio de Janeiro, v.14, n.50, 57-76, jan./mar.

SAITo, Hidetoshi. 2008. EFL classroom peer assessment: training effects on rating and commenting. Language Testing, v. 25, n.4, 553-581. Available at: $<$ http://tj.sagepub.com/content/25/4/553 $>$.

Salomão, Ana Cristina Biondo. 2008. Gerenciamento e estratégias pedagógicas na mediação dos pares no teletandem e seus reflexos para as práticas pedagógicas dos interagentes. Dissertation (Master's in Linguistic Studies) - São Paulo State University, São José do Rio Preto, São Paulo, Brazil.

SAntos, Gerson Rossi dos. 2008. Características da interação no contexto de aprendizagem in-tandem. Dissertation (Master's in Linguistic Studies) - São Paulo State University, São José do Rio Preto, São Paulo, Brazil.

Scaramucci, Matilde Virginia Ricardi. 2006. O professor avaliador: sobre a importância da avaliação na formação do professor de língua estrangeira. In: L. Rottava. Ed. Ensino-aprendizagem de línguas: língua estrangeira. Ijuí, Brazil: Ed. UNIJUÍ, 49-64.

. 1999. Avaliação: mecanismo propulsor de mudanças no ensino/ aprendizagem de língua estrangeira. Contexturas, v. 4, 115-124.

. 1997. Avaliação de rendimento no ensino-aprendizagem de Português língua estrangeira. In: J. C. P. de Almeida Filho. Ed. Parâmetros atuais para o ensino de português língua estrangeira. Campinas, Brazil: Pontes Editores, 75-88.

. 1993. Dúvidas e questionamentos sobre a avaliação em um contexto de ensino de línguas. Proceedings of the V Semana de Letras. Maringá, Brazil: State University of Maringá, 91-98.

SCHLATTER, Margarete. 1999. Celpe-Bras: certificado de língua portuguesa para estrangeiros - breve histórico. In: M. J. C. Cunha \& P. Santos. Eds. Ensino e pesquisa em português para estrangeiros. Brasília, Brazil: Editora da UnB, 97-104.

SCHLATTER, Margarete et al. 2009. Impactos da construção de parâmetros comuns de avaliação de proficiência em português e espanhol. In: M. Zoppi-Fontana. Ed. O português do Brasil como língua transnacional. Campinas: RG Editora. 
2005. Avaliação de desempenho e os conceitos de validade, confiabilidade e efeito retroativo. In: V. N. Flores et al. Eds. A redação no contexto do vestibular 2005: a avaliação em perspectiva. Porto alegre: UFRGS: $11-35$.

Schoffen, Juliana Roquele. 2009. Gêneros do Discurso e Parâmetros de Avaliação de Proficiência em Português como Língua Estrangeira no Exame Celpe-Bras. Thesis (Doctorate in Applied Linguistics) Federal University of Rio Grande do Sul, Porto Alegre, Brazil.

. 2003. Avaliação de proficiência oral em língua estrangeira: descrição dos níveis de candidatos falantes de espanhol no exame Celpe-Bras. Dissertation (Master's in Applied Linguistics) - Federal University of Rio Grande do Sul, Porto Alegre, Brazil.

SHонамy, Elana \& InBAR, Ofra. 2006a. The language assessment process: a "multiplism" perspective. CALPER Professional development document 0603. University Park, PA: The Pennsylvania State University, Center for Advanced Language Proficency Education Research.

2006b. Assessment of advanced language proficiency: why performance-based task? CALPER.

Silva, Marco \& SAntos, Edméa. Eds. 2006. Avaliação da aprendizagem em educação online. São Paulo, Brazil: Edições Loyola.

SiLvA, Andressa Carvalho da. 2008. O desenvolvimento intra-interlinguístico in-tandem a distância (português e espanhol). Dissertation (Master's in Linguistic Studies) - São Paulo State University, São José do Rio Preto, São Paulo, Brazil.

Stefani, Lorraine. 1994. 'Peer, self and tutor assessment: Relative reliabilities'. Studies in Higher Education, v.19, n.1, 69-75. Available at: $<\mathrm{http}: / / d x$.doi.org/10.1080/03075079412331382153>.

Telles, João Antonio. 2015. Teletandem and performativity. Rev. bras. linguist. apl. [online]. vol.15, n.1, 1-30. Available at: <http://www. scielo.br/pdf/rbla/v15n1/1984-6398-rbla-15-01-00001.pdf $>$.

Telles, João Antonio. Ed. 2009. Teletandem: um contexto virtual, autônomo e colaborativo para a aprendizagem de línguas estrangeiras no século $X X I$. Campinas, Brazil: Pontes Editores.

Telles, João Antonio \& VAssallo, Maria Luisa. 2006. Foreign language learning in-tandem: Teletandem as an alternative proposal in CALLT. The ESPecialist, v. 27, n. 2, 189-212.

Vassallo, Maria Luisa. 2010. Relações de poder em parcerias de teletandem. Thesis (Doctorate in Linguistic Studies) - São Paulo State University, São José do Rio Preto, São Paulo, Brazil.

Vassallo, Maria Luisa \& Telles, João Antonio. 2006. Foreign language learning in-tandem: theoretical principles and research perspectives. The ESPecialist, 25 (1), 1-37, 2006. 